\title{
Improvement in Metal Dissolution from Spent Catalyst by Adapted Acidithiobacillus ferrooxidans
}

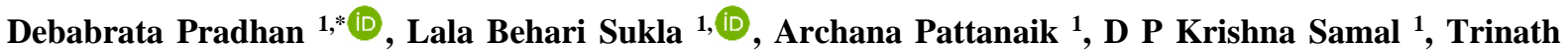 \\ Biswal $^{2}$, Sushant Kumar Bad Jena ${ }^{2}$ \\ 1 Biofuels and Bioprocessing Research Center, ITER, Siksha 'O' Anusandhan (Deemed to be University), Bhubaneswar- \\ 751030, India \\ 2 Veer Surendra Sai University of Technology, Burla-768018, India \\ * Correspondence: debabratapradhan@soa.ac.in; dpradhanmetal@gmail.com;
}

Scopus Author ID 24462349600

Received: 3.06.2020; Revised: 29.06.2020; Accepted: 1.07.2020; Published: 4.07.2020

\begin{abstract}
The improvement in the leaching rate of Ni, V, Mo, and Al present in a spent catalyst sample was evaluated by the bacterial adaptation technique. For this purpose, leaching of the metals from the spent catalyst sample was conducted using both adapted and unadapted bacteria cultures. The evaluation was done on the basis of the variation of different leaching parameters such as $\mathrm{pH}$, temperature, particle size, pulp density, and initial Fe(II) concentration. The adaptation technique was found to be fruitful as the leaching equilibrium reduced from 240 to $40 \mathrm{hr}$. Further, the leaching rate of $\mathrm{Ni}$ and $\mathrm{V}$ was improved by $10 \%(w / w)$ due to bacterial adaptation. The leaching rate of Mo was lower due to combining the action of different factors like the presence of impervious elemental sulfur, refractory nature, and low solubility. The lower leaching rate of $\mathrm{Al}$ observed due to the refractoriness of the alumina matrix present in the spent catalyst sample. The pseudo rate order with respect to all leaching parameters was determined and found to be significant for the adaptation process.
\end{abstract}

Keywords: Bioleaching; Adaptation; Spent catalyst; Leaching parameter; Iron oxidizing bacteria.

(C) 2020 by the authors. This article is an open-access article distributed under the terms and conditions of the Creative Commons Attribution (CC BY) license (https://creativecommons.org/licenses/by/4.0/).

\section{Introduction}

Oxides of $\mathrm{Mo}, \mathrm{Ni}$, and $\mathrm{Co}$ are used as catalysts in the petroleum refinery process for the purpose of the purification of different petroleum distillates and residues. They develop some deficiency in their physical properties after several usage cycles, which do not allow them for the purpose and are discarded as solid waste [1,2]. This solid waste is named as a spent catalyst (SC). The worldwide generation of SC is estimated to be 700,000-900,000metric ton/year [3]. The SC contains different metallic and nonmetallic elements like Al, V, Mo, Co, Ni, Fe, S, and C. Further, their high concentration in the SC sample does not allow it for a free landfill purpose as there are some obligations to dispose of the hazardous substance set by the environmental protection agencies of different countries [4]. Management of such a huge amount of SC become a headache for the petroleum refineries establishments. In order to utilize the SC values, a different group of researchers is working in their research horizons [5-8]. One of them is the dissolution of different valuable metals from the SC through hydrometallurgical technique, followed by their recovery for the development of usable products [9-14].

In the hydrometallurgical technique, the $\mathrm{SC}$ is generally roasted, followed by the metal dissolution using different suitable leaching reagents [7-10,14-20]. It can be leached directly at the high pressure $[13,21]$. However, these hydrometallurgical techniques are intensive in terms 
of chemicals and energy. In order to overcome the issues related to the conventional leaching process, bioleaching has emerged in the biotechnology era. Indeed, different naturally occurring microorganisms have shown the tremendous ability of metal dissolutions from different solid resources [22-26].

The microorganism genera like Acidithiobacilli spp., Pseudomonas spp., Aspergillus spp., and Penicillium spp has been examined by different bioleaching groups for the dissolution of different metals from a range of solid resources [27-35]. Acidithiobacillus ferrooxidans is one of them, which has proved its significance in the bioleaching of different metals by using its inborn quality of oxidation of ferrous and sulfur to ferric iron and sulfuric acid, respectively. During its metabolism, it helps the metal dissolution either by the direct cellular activity or indirect reactions compensated by the metabolic products [36].

However, in some cases, bacteria are not compatible with the leaching medium containing solid resources. There are different reasons for it. There may be some unwanted metals present in the solid samples which impede the growth of bacteria. Secondly, there may be a trace amount of toxic elements present in the solid samples. They create physiological stress in the life cycle of bacteria. As a result, either their population decreases or, in the worse case, they may die. In this case, the bacterial adaptation cumulates the leaching properties [3739]. The bacterial adaptation process is a field type mutation process that does not require any molecular cloning of the bacterial gene. In this process, the bacteria resume the metabolic properties slowly by adopting the adverse environment and overcome the physiological stress. Further, the toxicity developed by different trace elements present in the solid samples during the bioleaching process can be suppressed by the adaptation [40]. Furthermore, the adapted bacteria can improve the leaching rate [38].

Although adaptation is a known process for the leaching improvement, its application in the SC bioleaching is not adequate. Therefore, bioleaching of a SC sample using the adapted bacteria and evaluation of its improvement is the main purpose of this article.

\section{Materials and Methods}

\subsection{Chemicals.}

Only analytical grade chemicals and de-ionized water were used whenever required.

\subsection{Pretreatment of SC sample.}

The petrochemical SC sample coated with waste oil, which was removed in the boiled acetone with the help of a soxhlet. The de-oiled SC sample was then dried and followed by ground with the help of a mortar and pestle. Then the SC powder sample was sieved to get different particle size fractions. The SC powder sample was then undergone an acid digestion process, and the digested liquor was analyzed using ICP-AES (JOBIN-YVON JY 38). The concentration of $\mathrm{Al}, \mathrm{S}, \mathrm{Ni}, \mathrm{V}, \mathrm{Mo}$, and $\mathrm{C}$ in the $\mathrm{SC}$ powder sample was found to be $19.5,11.5,2.0,9.0,1.4$, and $2.5 \%$, respectively.

\subsection{Microorganisms.}

The bacterium used in the bioleaching experiments was $A$. ferrooxidans, which was isolated from a water sample collected from the Dalsung copper project of South Korea[41]. The bacterium was sub-cultured in freshly prepared $9 \mathrm{~K}$ medium at $\mathrm{pH} 1.8$ and $35^{\circ} \mathrm{C}$. Further, 
the bacterium was sub-cultured repeatedly in the media with the same condition in order to achieve the highest iron oxidation rate[41]. This active culture was used in the leaching process was called unadapted bacteria culture (UBC).

\subsection{Adaptation.}

For the purpose of adaptation, the bacteria was repeatedly sub-cultured with the mimic version of $9 \mathrm{~K}$ media+SC sample. Since the SC sample has metals like Ni, V, and Mo, the fresh media was prepared with the addition of the above metals. In the initial sub-culture, the concentration was less. However, the concentration of the metals was increased gradually with the number of sub-culturing[42]. The concentration of $\mathrm{Ni}, \mathrm{V}$, and Mo were increased up to 10.0,5.0 and $0.03 \mathrm{~g} / \mathrm{L}$, respectively, on the basis of tolerance ability of the bacteria. Then the bacterium was further sub-cultured in the $9 \mathrm{~K}$ media with the addition of SC sample. The adaptation process was done until the SC concentration increased up to $20 \mathrm{~g} / \mathrm{L}$. After the repeated sub-culturing in the presence of SC sample, the iron oxidation rate became the same as that in the case of UBC. This adapted bacteria culture was named as ABC.

\subsection{Bioleaching.}

The leaching experiments were conducted in the $250 \mathrm{~mL}$ shake flasks, which contained $100 \mathrm{~mL}(90 \mathrm{~mL}$ of media and $10 \mathrm{~mL}$ of inoculums, i.e., UBC or ABC) of the lixiviant. The shaking of the lixiviant was done with the help of an orbital shaker-cum-incubator at an average speed of 180rpm. The time of each leaching run was counted after adding the SC powder sample based on the pulp density. The $\mathrm{pH}$ and Eh of the lixiviant were monitored in fixed time intervals using a $\mathrm{pH}$-Eh meter(THERMO, ORION-720+). Also, samples were collected in regular time intervals for the evaluation of metal dissolution. The metal ion concentration in the leach liquor was analyzed using ICP-AES(JOBIN-YVON JY 38). The leaching studies were conducted at $\mathrm{pH}-2.0$, pulp density(PD)-10\%(w/v), temperature-35 ${ }^{\circ} \mathrm{C}, \mathrm{Fe}(\mathrm{II})-10 \mathrm{~g} / \mathrm{L}$, and particle size(PS)-106 $\mu \mathrm{m}$, unless otherwise specified. The effect of different parameters on the leaching rate was examined and discussed in each sub-section. All experiments were triplicated, and the experimental errors were within $\pm 3 \%$.

\section{Results and Discussion}

\subsection{Equilibrium time.}

In order to evaluate the equilibrium time of the leaching of four metals (e.g., $\mathrm{Al}, \mathrm{Ni}$, Mo, and V) from the SC sample using the UBC, the experiments were conducted for $300 \mathrm{hr}$. The leaching rate of the metals is shown in Fig.1. It can be observed that the leaching rate changed hardly after $240 \mathrm{hr}$. Therefore, the equilibrium time of leaching using UBC was $240 \mathrm{hr}$, and further, all leaching experiments using the UBC were conducted for $240 \mathrm{hr}$. When the equilibrium time of the leaching using the $\mathrm{ABC}$ was evaluated, there was hardly any change in the metal leaching observed after 40hr (Fig.1). Therefore, the equilibrium time of the metal leaching using the $\mathrm{ABC}$ was set for $40 \mathrm{hr}$, and all further leaching experiments were limited to the equilibrium time. The leaching rate of $\mathrm{Ni}$ and $\mathrm{V}$ was found to be about $85 \%$ in the case of UBC; however, those were about $95 \%$ in the case of ABC. This showed that bacterial adaptation not only improved the leaching rate by $10 \%$; it also decreased the equilibrium time significantly. However, the leaching rate of $\mathrm{Al}$ and Mo were not encouraging for both the 
cultures. Al leaching was not affected by the adaptation process (Fig.1). It means the bacterial dissolution of $\mathrm{Al}$ was not occurred due to the refractoriness of the $\mathrm{Al}_{2} \mathrm{O}_{3}$ matrix[43]. The leaching rate of Mo increased due to adaptation; however, it was not similar to Ni and $\mathrm{V}$. The lower Mo leaching observed due to the mutual effect of the refractoriness of $\mathrm{MoS}_{2}$ matrix, lower solubility of Mo in the mild acidic medium, and the impervious sulfur layer over the Momatrix [44].

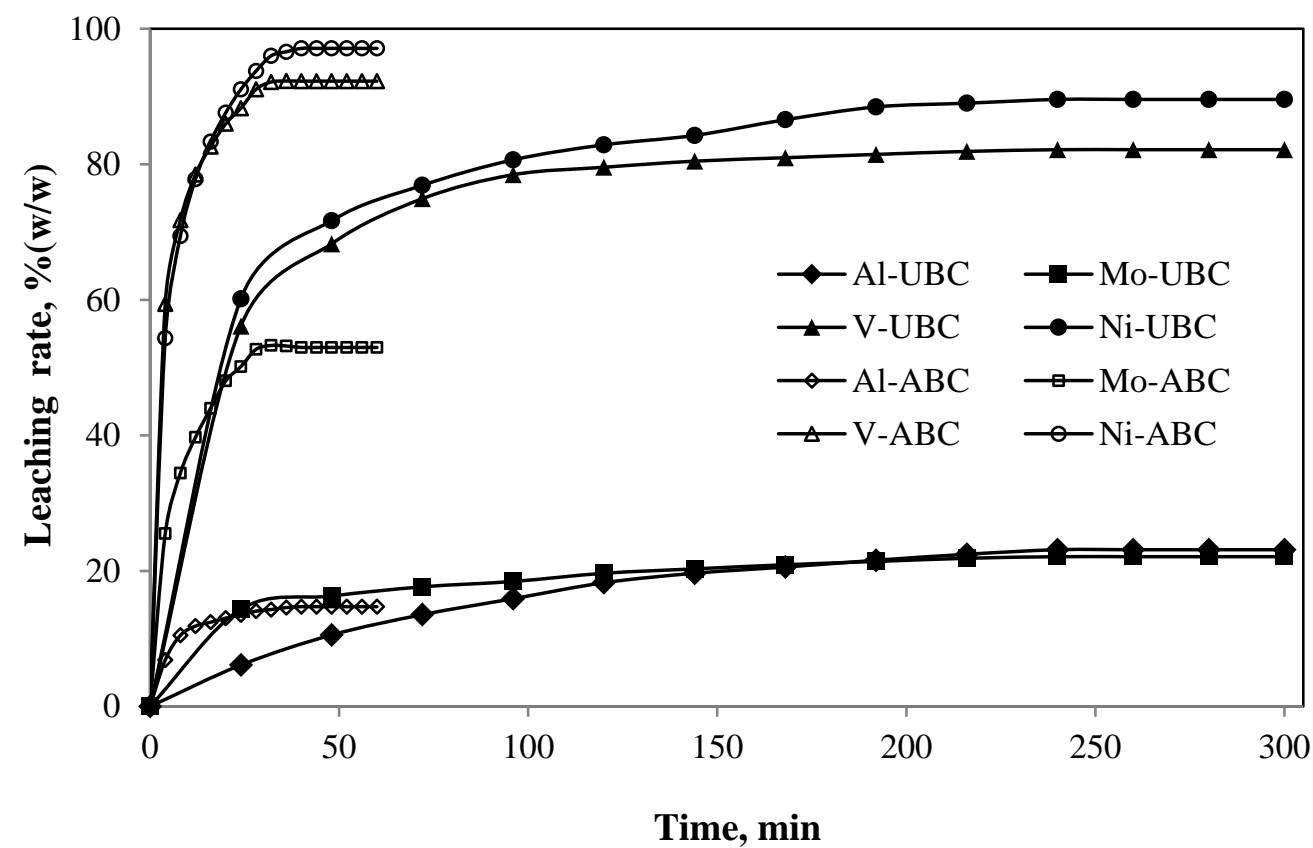

Figure 1. Effects of contact time on the dissolution of Ni, V,Mo, and $\mathrm{Al}$ by both $\mathrm{UBC}$ and $\mathrm{ABC}$. Conditions:Fe(II)-10g/L, pulp density-10\%(w/v),pH-2.0, particle size $-106+45 \mu \mathrm{m}$, temperature- $35^{\circ} \mathrm{C}$ and $180 \mathrm{rpm}$.

\subsection{Effect of $p H$.}

The initial $\mathrm{pH}$ of the lixiviant was varied as $1.5,1.75,2.0,2.25,2.5,2.75$, and 3.0, while other parameters kept constant, as mentioned in the experimental section. The $\mathrm{pH}$ of the lixiviant was adjusted by adding dilute $\mathrm{H}_{2} \mathrm{SO}_{4}(10 \%)$ in the leaching medium. Figure 2 shows the leaching rate of metals from the $\mathrm{SC}$ sample by varying $\mathrm{pH}$ of the medium using both $\mathrm{ABC}$ and UBC. The leaching rate increased from $\mathrm{pH} 1.5$ to 2.0; however, it decreased with a further increase in the $\mathrm{pH}$. This leaching pattern was due to the bacterial activity increased when the $\mathrm{pH}$ of the medium increased from $\mathrm{pH} 1.5$ to 2.0, and it decreased at a higher $\mathrm{pH}$ [45]. Further, the formation of jarosite in the leaching medium at a higher $\mathrm{pH}$ may be another reason for the falling leaching rate at the higher $\mathrm{pH}$ range[46]. However, the adaptation process showed beneficial at the optimum $\mathrm{pH}$ of 2.0. Since the bacterial activity was at the peak at $\mathrm{pH} 2.0$, the $\mathrm{ABC}$ efficiently dissolved the metals over UBC at the optimum $\mathrm{pH}$.

\subsection{Effect of initial $\mathrm{Fe}(I I)$.}

The initial Fe(II) concentration was varied as $0,5,10,15,20,25$, and $30 \mathrm{~g} / \mathrm{L}$ while other parameters kept constant as mentioned and the result of metal leaching from the SC sample using both $\mathrm{ABC}$ and UBC is shown in Fig.3. The leaching rate increased with the increase of $\mathrm{Fe}$ (II) concentration from 0 to $10 \mathrm{~g} / \mathrm{L}$, and it decreased upon further increase of $\mathrm{Fe}(\mathrm{II})$ concentration. However, the $\mathrm{ABC}$ showed better results over the UBC in all range of the $\mathrm{Fe}(\mathrm{II})$ concentration for three metals such as $\mathrm{Ni}, \mathrm{V}$, and Mo. 


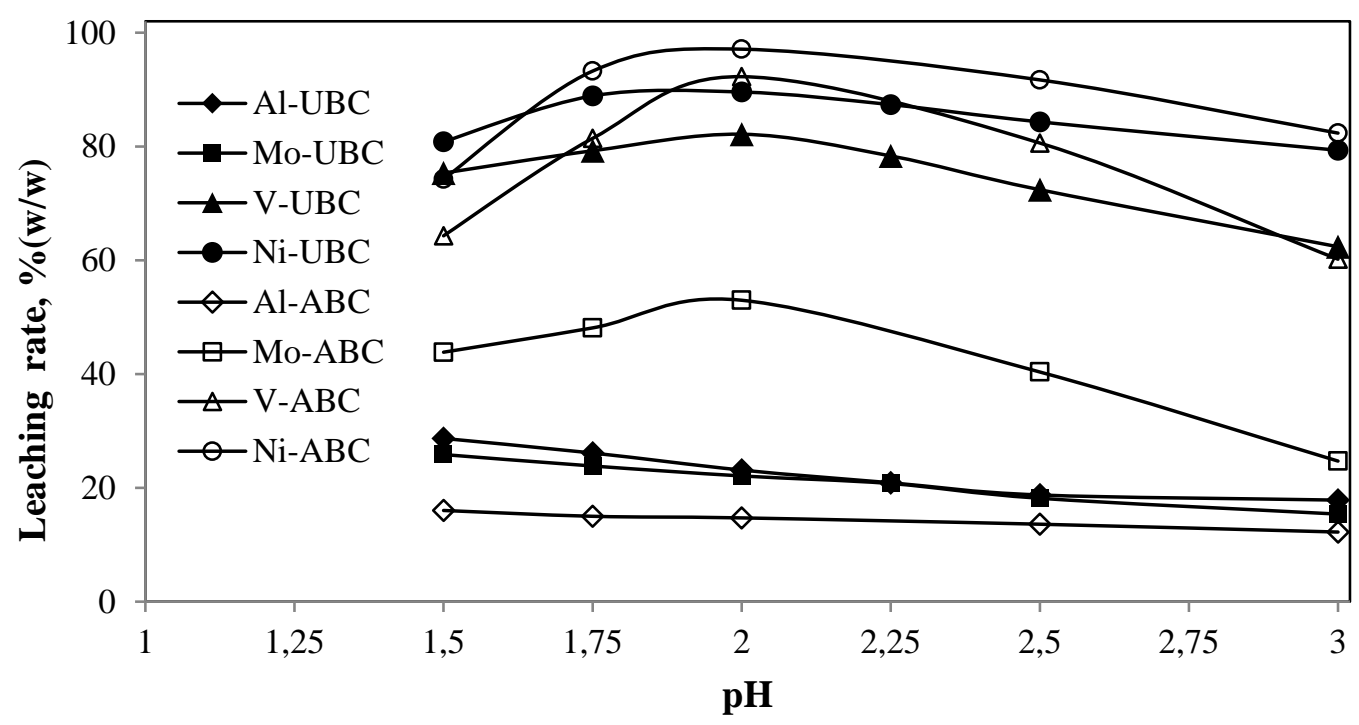

Figure 2. Effects of $\mathrm{pH}$ on the leaching of SC sample by both UBC and ABC. Conditions:Fe(II)-10g/L,pulp density-10\%(w/v), particle size- $106+45 \mu \mathrm{m}$,temperature- $35^{\circ} \mathrm{C}$ and $180 \mathrm{rpm}$.

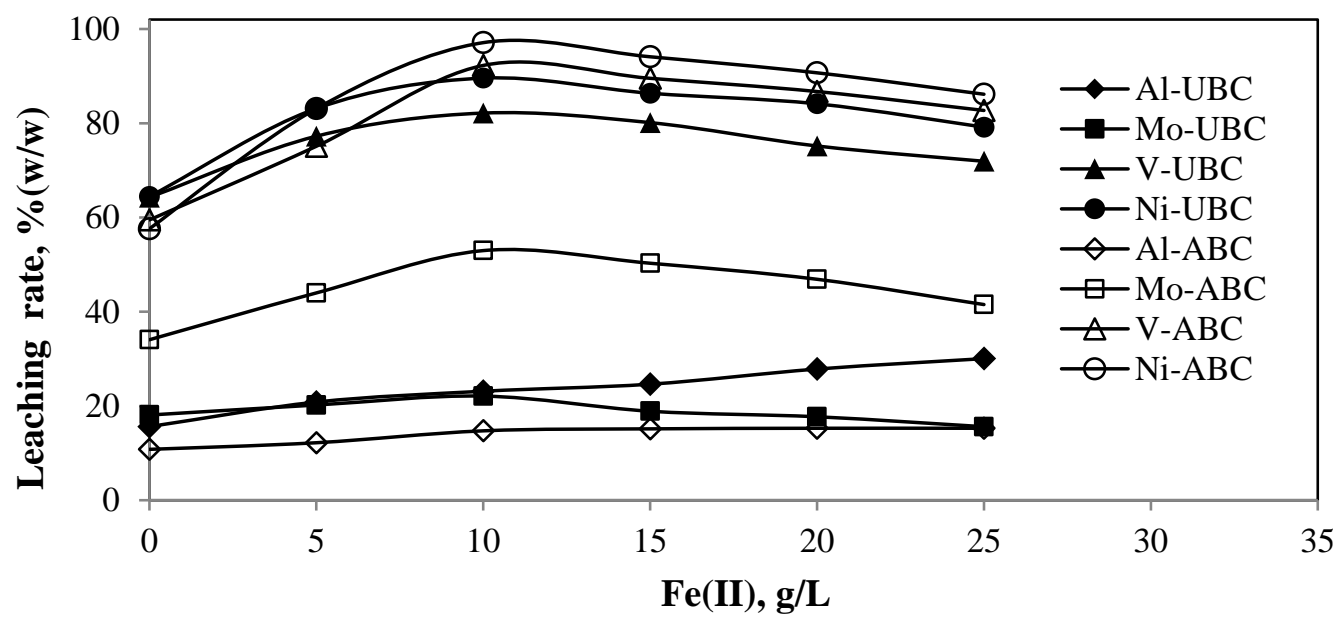

Figure 3. Effects of $\mathrm{Fe}(\mathrm{II})$ concentration on the dissolution of $\mathrm{Ni}, \mathrm{V}, \mathrm{Mo}$, and $\mathrm{Al}$ from the $\mathrm{SC}$ sample using both UBC and ABC. Conditions:pulp density-10\%(w/v),pH-2.0,particle size-106 $+45 \mu \mathrm{m}$, temperature- $35^{\circ} \mathrm{C}$ and $180 \mathrm{rpm}$.

\subsection{Effect of pulp density.}

The pulp density was varied from 5 to $30 \%(\mathrm{w} / \mathrm{v})$ while other parameters kept constant as mentioned and the result of metal leaching from the SC sample using both ABC and UBC is shown in Fig.4. The leaching rate constantly decreased with the increase of pulp density for both $\mathrm{ABC}$ and UBC. At the lower pulp density, the solid sample gets adequate chemical reaction environment; however, at the higher pulp density, the solid sample was much more for the reaction environment. Further, when the number of solid particles increased, the competitive solid particles for the attacking reagent hindered the chemical reactions[44]. If the pulp density of $5 \%(\mathrm{w} / \mathrm{v})$ is considered, the leaching rate of $\mathrm{Ni}$ and $\mathrm{V}$ increased by more than $10 \%$ with the application of the bacterial adaptation process. 


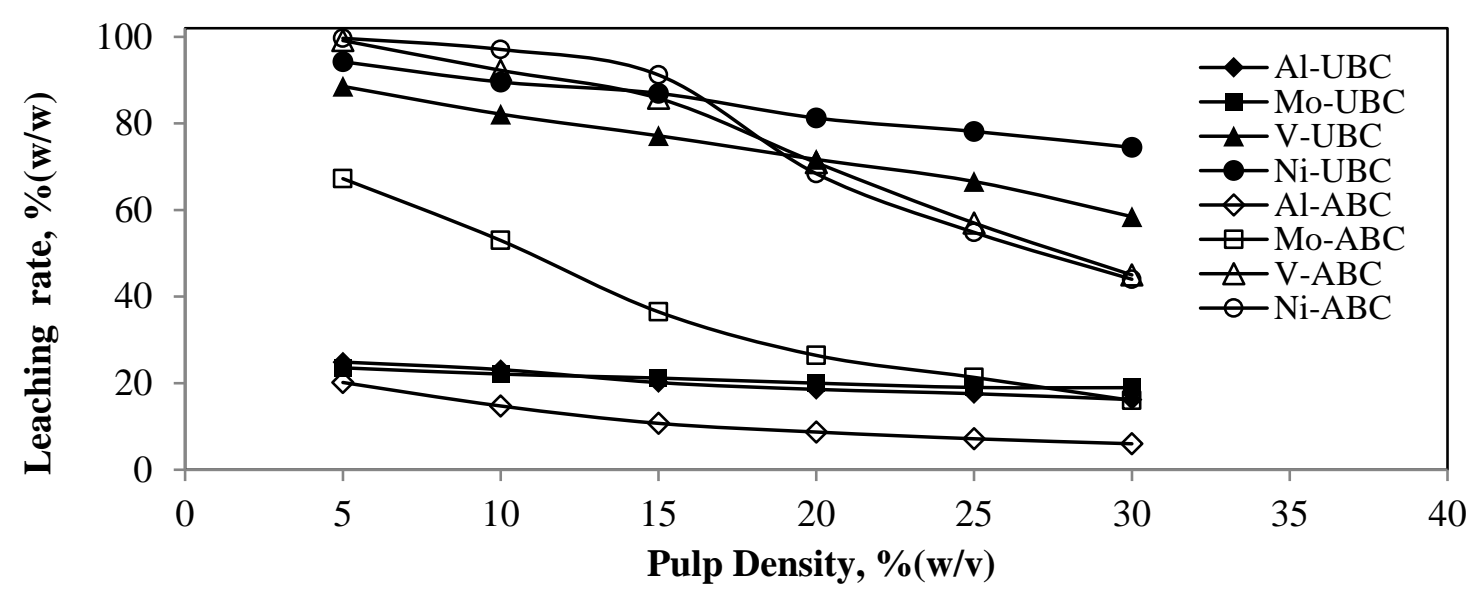

Figure 4. The effects of pulp density on the dissolution of $\mathrm{Ni}, \mathrm{V}, \mathrm{Mo}$, and $\mathrm{Al}$ from the $\mathrm{SC}$ sample using both UBC and ABC. Conditions:Fe(II)-10g/L,pH-2.0,particle size $-106+45 \mu \mathrm{m}$, temperature- $35^{\circ} \mathrm{C}$ and $180 \mathrm{rpm}$.

\subsection{Effect of particle size.}

The particle size range of the SC sample was $-45,-106+45$, and $-212+106 \mu \mathrm{m}$ while other parameters kept constant, and the result of metal leaching from the SC sample using both $A B C$ and UBC is shown in Fig 5. The leaching rate of all four metals decreased with the increase of particle size for both the bacterial culture; however, the decrease rate was observed to be insignificant. Since our main aim to evaluate the improvement of the leaching rate due to bacterial adaptation, it was found to be beneficial for the wide range of particle size used in the leaching experiments.

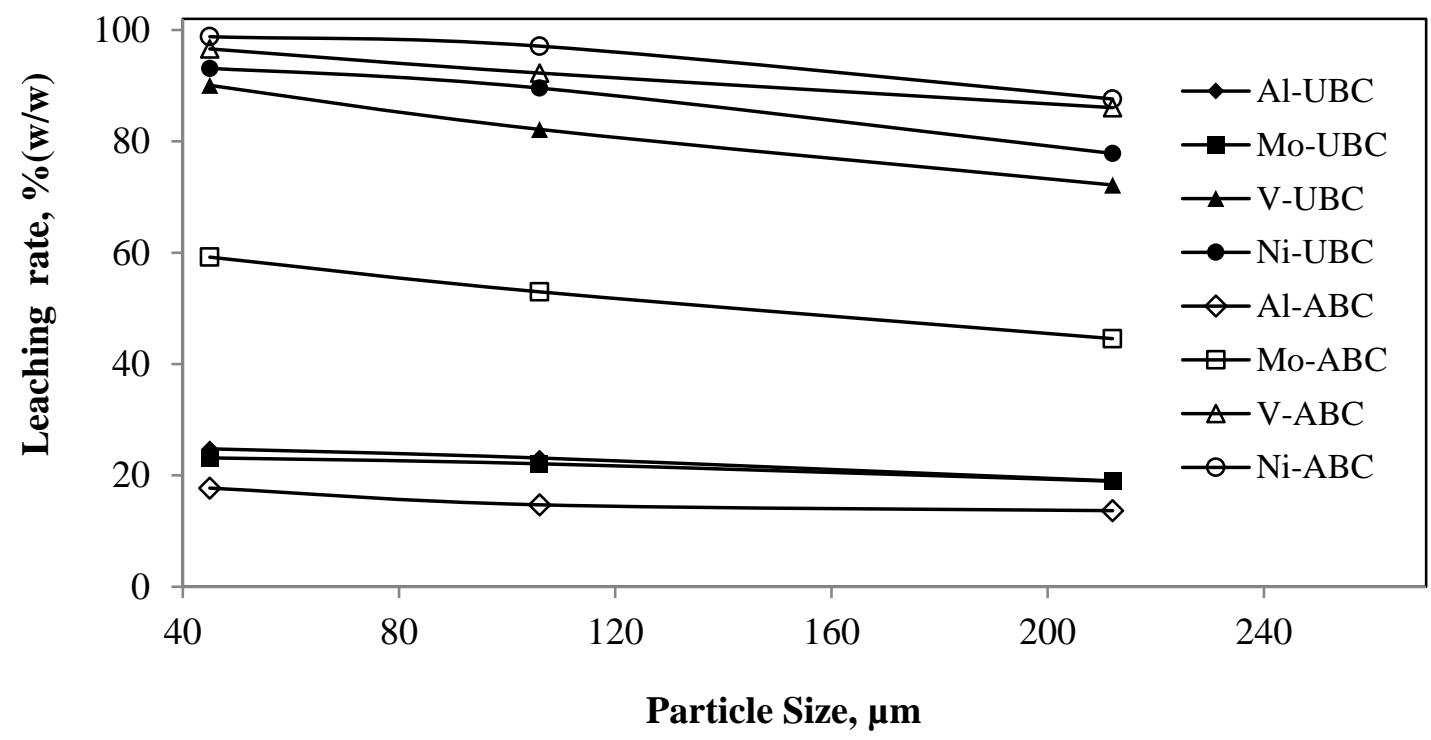

Figure 5. The effects of particle size on the dissolution of $\mathrm{Ni}, \mathrm{V}, \mathrm{Mo}$, and $\mathrm{Al}$ from the $\mathrm{SC}$ sample using both UBC and ABC. Conditions:Fe(II)-10g/L,pulp density-10\%(w/v),pH-2.0,temperature-35 ${ }^{\circ} \mathrm{C}$ and $180 \mathrm{rpm}$.

\subsection{Effect of temperature.}

The temperature was varied from 10 to $35^{\circ} \mathrm{C}$ while other parameters kept constant for both $\mathrm{ABC}$ and UBC. The result of the leaching rate of metals from the SC sample using both $\mathrm{ABC}$ and $\mathrm{UBC}$ is shown in Fig.6. The leaching rate increased with the increase of temperature from 10 to $35^{\circ} \mathrm{C}$, and thereafter it decreased. At temperature $35^{\circ} \mathrm{C}$, it can be observed that the $\mathrm{ABC}$ leached $\mathrm{Ni}, \mathrm{V}$, and Mo efficiently in comparison to the UBC due to the higher activity of 
the adapted bacteria culture. From the temperature variation study, it can be observed that the leaching reactions were endothermic in nature.

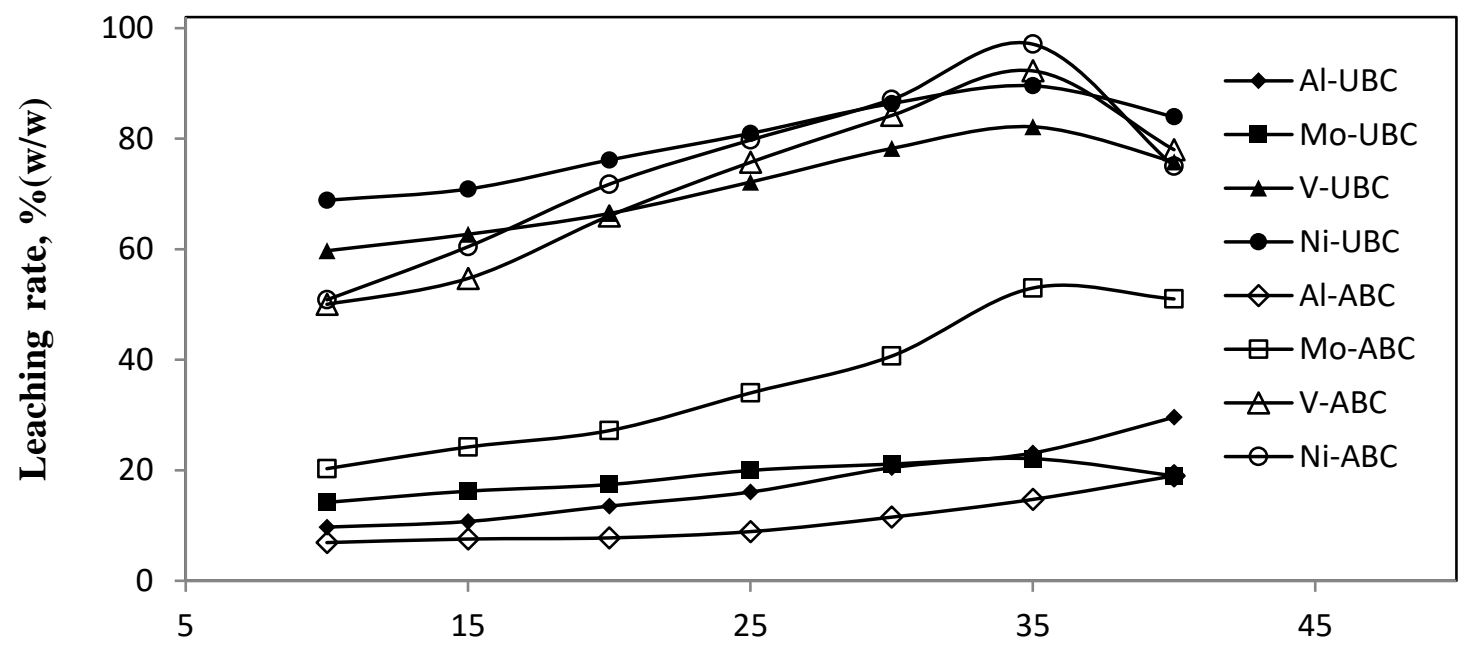

Temperature, ${ }^{\circ} \mathrm{C}$

Figure 6. The effects of temperature on the dissolution of $\mathrm{Ni}, \mathrm{V}, \mathrm{Mo}$, and $\mathrm{Al}$ from the $\mathrm{SC}$ sample using both

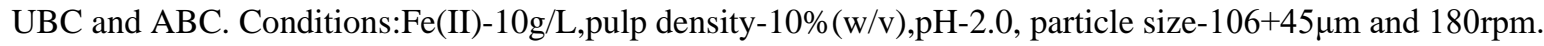

\subsection{Pseudo rate order.}

The leaching reactions were observed to be dependent on different leaching parameters. So the rate equation with respect to the parameter can be written as the equation given in Eq.1.

$$
\text { Rate } \propto \text { Parameter }{ }^{n}
$$

where $n=$ dependence factor of the parameter or the order of the leaching reaction with respect to the parameter. The Eq.1 can be written as the equation given in Eq. 2 by using a proportionality constant.

$$
\text { Rate }=\mathrm{k} \times \text { Parameter }^{\mathrm{n}}
$$

where $\mathrm{k}=$ proportionality constant. If all parameters are used in the Eq.2, it can be written as the equation given in Eq.3.

$$
\text { Rate }=k \times[p H]^{n_{1}} \times[P D]^{n_{2}} \times[F e(I I)]^{n_{3}} \times[P S]^{n_{4}} \times[\text { Temp }]^{n_{5}}
$$

where, $\mathrm{n}_{1}, \mathrm{n}_{2}, \mathrm{n}_{3}, \mathrm{n}_{4}$, and $\mathrm{n}_{5}$ are the pseudo order of the leaching reactions with respect to the parameters such as $\mathrm{pH}$, PD (pulp density), Fe(II) concentration, PS (particle size), and temperature, respectively. The logarithm form of the Eq. 3 can be expressed as the equation given in Eq.4.

$\log [$ Rate $]=\log [\mathrm{k}]+\mathrm{n}_{1} \log [\mathrm{pH}]+\mathrm{n}_{2} \log [\mathrm{PD}]+\mathrm{n}_{2} \log [\mathrm{Fe}(\mathrm{II})]+\mathrm{n}_{4} \log [\mathrm{PS}]+$ $\mathrm{n}_{5} \log [\mathrm{Temp}]$

Since the leaching rate of $\mathrm{Ni}$ and $\mathrm{V}$ were observed to be significant, the pseudo rate order of five parameters for them was evaluated from the slopes of the logarithmic graph of $\log$ (Rate) plotted versus $\log$ (parameters) for both $\mathrm{ABC}$ and UBC. For a particular parameter other parameters were kept constant in order to evaluate the pseudo rate order with respect to that parameter (e.g., for the determination pseudo rate order with respect to $\mathrm{pH}$, the other parameter, such as PD, Fe(II), PS and temperature were kept constant). The values of the pseudo rate order of $\mathrm{Ni}$ and $\mathrm{V}$ for different parameters and bacterial cultures are given in Table 1. From the pseudo rate order values, it can be concluded that the ABC categorically improved the leaching rate of $\mathrm{Ni}$ and $\mathrm{V}$ for all parameters over the UBC. 
Table 1. Values of pseudo rate order of $\mathrm{Ni}$ and $\mathrm{V}$ for both $\mathrm{ABC}$ and UBC.

\begin{tabular}{l|l|l|l|l}
\multirow{2}{*}{ Pseudo rate order } & $\mathrm{Ni}$ & $\mathrm{V}$ & \\
\cline { 2 - 5 } & $\mathrm{UBC}$ & $\mathrm{ABC}$ & $\mathrm{UBC}$ & $\mathrm{ABC}$ \\
\hline $\mathrm{n}_{1}$ & -0.3 & -0.4 & -0.7 & -1.0 \\
\hline $\mathrm{n}_{2}$ & -0.218 & -1.041 & -0.384 & -0.921 \\
\hline $\mathrm{n}_{3}$ & -0.126 & -0.126 & -0.147 & -0.114 \\
\hline $\mathrm{n}_{4}$ & -0.113 & -0.075 & -0.141 & -0.073 \\
\hline $\mathrm{n}_{5}$ & 0.221 & 0.513 & 0.261 & 0.511
\end{tabular}

\section{Conclusions}

The isolated iron-oxidizing bacteria showed the ability of $\mathrm{Ni}, \mathrm{V}, \mathrm{Mo}$, and $\mathrm{Al}$ dissolution capacity from the SC sample. The leaching rate of Ni, V, and Mo was further increased by $10 \%$ due to the bacterial adaptation process. However the leaching rate of Mo and $\mathrm{Al}$ was found to be very slow compared to that of $\mathrm{Ni}$ and $\mathrm{V}$. The slow Mo leaching was due to the mutual effect of the refractoriness of $\mathrm{MoS}_{2}$, lower solubility of Mo in the mild acidic medium, and the impervious sulfur layer over the Mo-matrix. The lower leaching rate of $\mathrm{Al}$ was due to the refractoriness of the $\mathrm{Al}_{2} \mathrm{O}_{3}$ matrix present in the $\mathrm{SC}$ sample. The equilibrium time of the leaching reaction was reduced from 240 to the only $40 \mathrm{hr}$ due to the bacterial adaptation process. Since the equilibrium time of bioleaching is its major drawback, this adaptation process was found to be fruitful for the higher scale implementation of the bioleaching process in order to extract the metal values from the SC sample. The improvement of leaching was confirmed by variation of five leaching parameters such as $\mathrm{pH}$, pulp density, initial $\mathrm{Fe}(\mathrm{II})$ concentration, the particle size of the SC sample, and temperature. The pseudo rate orders of all parameters were found to be significant for the adaptation process. In the final conclusion, the SC sample can be utilized by the bioleaching process in order to recover different metal values present in it; however, a simple adaptation process is required for the development of an efficient bioleaching process.

\section{Funding}

This research received no external funding.

\section{Acknowledgments}

The authors are grateful to Prof(Dr.)M.R.Nayak, President, Siksha 'O'Anusandhan (Deemed to be University), for providing the infrastructures and encouragement throughout.

\section{Conflicts of Interest}

The authors declare no conflict of interest.

\section{References}

1. Marafi, M.; Stanislaus, A. Spent catalyst waste management: A review Part-I-Developments in hydroprocessing catalyst waste reduction and use. Resour. Conserv. Recycl. 2008, 52, 859-873, https://doi.org/10.1016/j.resconrec.2008.02.004.

2. Zhang, L.; Song, Q.; Liu, Y.; Xu, Z. Novel approach for recovery of palladium in spent catalyst from automobile by a capture technology of eutectic copper. J. Clean. Prod. 2019, 239, https://doi.org/10.1016/j.jclepro.2019.118093.

3. Ferella, F.; Innocenzi, V.; Maggiore, F. Oil refining spent catalysts: a review of possible recycling technologies. Resour. Conserv. Recycl. 2016, 108, 10-20, https://doi.org/10.1016/j.resconrec.2016.01.010. 
4. Fu, P.; Fang, Y.; Ma, L.; Jiang, X.; Liu, Y.; Lv, W.; Huang, Y; Wang, L.; Li, J.; Wang, H. Air acceleration classification for the enhancement of spent catalyst activity classification. Sep. Pur. Technol. 2019, 223, 3140, https://doi.org/10.1016/j.seppur.2019.04.037.

5. Akcil, A.; Vegliò, F.; Ferella, F.; Okudan, M.D.; Tuncuk, A. A review of metal recovery from spent petroleum catalysts and ash. Waste Manage. 2015, 45, 420-433, https://doi.org/10.1016/j.wasman.2015.07.007.

6. Nancharaiah, Y.V.; Mohan, S.V.; Lens, P.N.L. Metals removal and recovery in bioelectrochemical systems: A review. Bioresour. Technol. 2015, 195, 102-114, https://doi.org/10.1016/j.biortech.2015.06.058.

7. Moon, G.; Kim, J.H.; Lee, J.Y.; Kang, J.S.Leaching of spent selective catalytic reduction catalyst using alkaline melting for recovery of titanium, tungsten, and vanadium. Hydrometallurgy 2019, 189, https://doi.org/10.1016/j.hydromet.2019.105132.

8. Liu, L.; Wang, L.; Su, S.; Yang, T.; Dai, Z.; Qing, M.; Xu, K.; Hu, S.; Wang, Y.; Xiang, J. Leaching behavior of vanadium from spent SCR catalyst and its immobilization in cement-based solidification/stabilization with sulfurizing agent. Fuel 2019, 243, 406-412, https://doi.org/10.1016/j.fuel.2019.01.160.

9. Busnardo, R.G.; Busnardo, N.G.; Salvato, G.N.; Afonso, J.C. Processing of spent NiMo and CoMo/Al2O3 catalysts via fusion with KHSO4. J. Hazard. Mater. 2007, 139, 391-398, https://doi.org/10.1016/j.jhazmat.2006.06.015.

10. Gaballah, I.; Diona, M. Valuable metals recovery from spent catalyst by selective chlorination. Resour. Conserv. Recycl. 1994, 10, 87-96, https://doi.org/10.1016/0921-3449(94)90041-8.

11. Santhiya, D.; Ting, Y.P. Bioleaching of spent refinery processing catalyst using Aspergillusnigerwith highyield oxalic acid. J. Biotechnol. 2005, 116, 171-184, https://doi.org/10.1016/j.jbiotec.2004.10.011.

12. Muddanna, M.H.; Baral, S.S. A comparative study of the extraction of metals from the spent fluid catalytic cracking catalyst using chemical leaching and bioleaching by Aspergillus niger. J. Environ. Chem. Eng. 2019, 7, https://doi.org/10.1016/j.jece.2019.103335.

13. Choi, I.H.; Moon, G.G.; Lee, J.Y.; Jyothi, R.K. Extraction of tungsten and vanadium from spent selective catalytic reduction catalyst for stationary application by pressure leaching process. J. Clean. Prod. 2018, 197, 163-169, https://doi.org/10.1016/j.jclepro.2018.06.196.

14. Su, Q.; Miao, J.; Li, H.; Chen, Y.; Chen, J.; Wang, J. Optimizing vanadium and tungsten leaching with lowered silicon from spent SCR catalyst by pre-mixing treatment. Hydrometallurgy 2018, 181, 230-239, https://doi.org/10.1016/j.hydromet.2018.10.003.

15. Park, K.H.; Mohapatra, D.; Nam, C.W. Two stage leaching of activated spent HDS catalyst and solvent extraction of Al using organo-phosphinic extractant, Cyanex-272. J. Hazard. Mater. 2007, 148, 287-295, https://doi.org/10.1016/j.jhazmat.2007.02.034.

16. Okazy, M.A.; Zewail, T.M.; Farag, H.A.M. Recovery of copper from spent catalyst using acid leaching followed by electrodeposition on square rotating cylinder. Alex. Eng. J. 2018, 57, 3117-3126, https://doi.org/10.1016/j.aej.2017.12.001.

17. Padh, B.; Rout, P.C.; Mishra, G.K.; Suresh, K.R.; Reddy, B.R. Recovery of nickel and molybdate from ammoniacal leach liquors of spent HDS catalysts using chelating ion exchange resin. Hydrometallurgy 2019, 184, 88-94, https://doi.org/10.1016/j.hydromet.2019.01.001.

18. Choi, I.H.; Kim, H.R.; Moon, G.G.; Jyothi, R.K.; Lee, J.Y. Spent V2O5-WO3/TiO2 catalyst processing for valuable metals by soda roasting-water leaching. Hydrometallurgy 2018, 175, 292-299, https://doi.org/10.1016/j.hydromet.2017.12.010.

19. Wu, W.; Wang, C.; Bao, W.; Li, H. Selective reduction leaching of vanadium and iron by oxalic acid from $\begin{array}{llllll}\text { spent } & \text { V2O5-WO3/TiO2 } & \text { catalyst. } & \text { Hydrometallurgy } & \mathbf{2 0 1 8}, & \text { 179, }\end{array}$ https://doi.org/10.1016/j.hydromet.2018.05.021.

20. Arslanoğlu, H.; Yaraş, A. Recovery of precious metals from spent Mo-Co-Ni/A12O3 catalyst in organic acid medium: Process optimization and kinetic studies. Petrol. Sci. Technol. 2019, 37, 2081-2093, https://doi.org/10.1080/10916466.2019.1618867.

21. Siemens, R.E.; Jong, B.W.; Russel, J.H. Potential of spent catalyst as a source of critical metals. Conserv. Recycl. 1986, 9, 189-196, https://doi.org/10.1016/0361-3658(86)90107-4.

22. Muddanna, M.H.; Baral, S.S. Leaching of nickel and vanadium from the spent fluid catalytic cracking catalyst by reconnoitering the potential of Aspergillus niger associating with chemical leaching. J. Environ. Chem. Eng. 2019, 7, https://doi.org/10.1016/j.jece.2019.103025.

23. Nagar, N.; Garg, H.; Gahan, C.S. Integrated bio-pyro-hydro-metallurgical approach to recover metal values from petroleum refinery spent catalyst. Biocatal. Agric. Biotechnol. 2019, 20, https://doi.org/10.1016/j.bcab.2019.101252.

24. Srichandan, H.; Mohapatra, R.K.; Parhi, P.K.; Mishra, S. Bioleaching approach for extraction of metal values from secondary solid wastes: A critical review. Hydrometallurgy 2019, 189, https://doi.org/10.1016/j.hydromet.2019.105122.

25. Sharma, S.; Rashmitha, C.S.; Pandey, L.M. Synthesis and characterization of methyl acrylamide cellulose nanowhiskers for environmental applications. Lett. Appl. NanoBioScience 2020, 9, 880-884, https://doi.org/10.33263/LIANBS91.880884. 
26. Pathak, J.; Sonker, A.S.; Rajneesh; Singh, V.; Kumar, D.; Sinha, R.P. Synthesis of silver nanoparticles from extracts of Scytonema geitleri HKAR-12 and their in vitro antibacterial and antitumor potentials. Lett. Appl. NanoBioScience 2019, 8, 576-585, https://doi.org/10.33263/LIANBS83.576585.

27. Brierley, J.A. A perspective on developments in biohydrometallurgy. Hydrometallurgy 2008, 94, 2-7, https://doi.org/10.1016/j.hydromet.2008.05.014.

28. Muddanna, M.H.; Baral, S.S. A bio-hydrometallurgical approach towards leaching of lanthanum from the spent fluid catalytic cracking catalyst using Aspergillus niger. Hydrometallurgy 2019, 184, 175-182, https://doi.org/10.1016/j.hydromet.2019.01.007.

29. Kim, H.I.; Moon, G.G.; Choi, I.H.; Lee, J.Y.; Jyothi, R.K. Hydrometallurgical process development for the extraction, separation and recovery of vanadium from spent desulfurization catalyst bio-leach liquors. $J$. Clean. Prod. 2018, 187, 449-458, https://doi.org/10.1016/j.jclepro.2018.03.247.

30. Pathak, A.; Srichandan, H.; Kim, D.J. Column bioleaching of metals from refinery spent catalyst by Acidithiobacillus thiooxidans: Effect of operational modifications on metal extraction, metal precipitation, and bacterial attachment. J. Environ. Manage. 2019, 242, 372-383, https://doi.org/10.1016/j.jenvman.2019.04.081.

31. Das, S.; Deshavath, N.K.; Goud, V.V.; Dasu, V.V. Bioleaching of Al from spent fluid catalytic cracking catalyst using Aspergillus species. Biotechnol. Rep. 2019, 23, https://doi.org/10.1016/j.btre.2019.e00349.

32. Pathak, A.; Healy, M.G.; Morrison, L. Changes in the fractionation profile of Al, Ni, and Mo during bioleaching of spent hydroprocessing catalysts with Acidithiobacillus ferrooxidans. J. Environ. Sci. Health A. 2018, 53, 1006-1014, https://doi.org/10.1080/10934529.2018.1471033.

33. Vyas, S.; Ting, Y.P. Microbial leaching of heavy metals using Escherichia coli and evaluation of bioleaching mechanism. Bioresour. Technol. Rep. 2020, 9, https://doi.org/10.1016/j.biteb.2019.100368.

34. Nazanin, T.N.; Horeh, B.; Mousavi, S.M. Environmentally friendly recovery of valuable metals from spent coin cells through two-step bioleaching using Acidithiobacillus thiooxidans. J. Environ. Manage. 2019, 235, 357-367, https://doi.org/10.1016/j.jenvman.2019.01.086.

35. Wei, D.; Liu, T.; Zhang, Y.; Cai, Z.; He, J.; Xu, C. Vanadium Bioleaching Behavior by Acidithiobacillus ferrooxidans from a Vanadium-Bearing Shale. Minerals 2018, 8, https://doi.org/10.3390/min8010024.

36. Pattanaik, A.; Sukla, L.B.; Pradhan, D.; Samal, D.P.K. Microbial mechanism of metal sulfide dissolution. Mater. Today Proceed. 2020, https://doi.org/10.1016/j.matpr.2020.01.615.

37. $\mathrm{Li}, \mathrm{H} . \mathrm{M}$; $\mathrm{Ke}$, J.J. Influence of $\mathrm{Ni} 2+$ and $\mathrm{Mg} 2+$ on the growth and activity of $\mathrm{Cu} 2+$ adapted Thiobacillus ferrooxidans. Hydrometallurgy 2001, 61, 151-156, https://doi.org/10.1016/S0304-386X(01)00167-0.

38. Ma, L.; Wang, H.; Wu, J.; Wang, Y.; Zhang, D.; Liu, X. Metatranscriptomics reveals microbial adaptation and resistance to extreme environment coupling with bioleaching performance. Bioresour. Technol. 2019, 280, 9-17, https://doi.org/10.1016/j.biortech.2019.01.117.

39. Zhang, X.; Shea, S.; Dong, W.; Niua, J.; Xiao, Y.; Lianga, Y.; Liua, X.; Zhang, X.; Fand, F.; Yin, H. Comparative genomics unravels metabolic differences at the species and/or strain level and extremely acidic environmental adaptation of ten bacteria belonging to the genus Acidithiobacillus. Syst. Appl. Microbiol. 2016, 39, 493-502, https://doi.org/10.1016/j.syapm.2016.08.007.

40. Elzeky, M.; Attia, Y.A. Effect of bacterial adaptation on kinetics and mechanisms of bioleaching ferrous sulfides. Chem. Eng. J. 1995, 56, B115-B124, https://doi.org/10.1016/0923-0467(94)06086-X.

41. Kim, D.J.; Pradhan, D.; Park, K.H.; Ahn, J.G.; Lee, S.W. Effect of pH and temperature on iron oxidation by mesophilic mixed iron oxidizing microflora. Mater. Trans. 2008, 49, 2389-2393, https://doi.org/10.2320/matertrans.MER2008051.

42. Pradhan, D.; Ahn, J.G.; Kim, D.J.; Lee, S.W. Effect of Ni2+, V4+ and Mo6+ concentration on iron oxidation by Acidithiobacillus ferrooxidans. Kor. J. Chem. Eng. 2009, 26, 736-741, https://doi.org/10.1007/s11814009-0123-9.

43. Pradhan, D.; Mishra, D.; Kim, D.J.; Roychaudhury, G.; Lee, S.W. Dissolution kinetics of spent petroleum catalyst using two different acidophiles. Hydrometallurgy 2009, 99, 157-162, https://doi.org/10.1016/j.hydromet.2009.07.014.

44. Pradhan, D.; Kim, D.J.; Sukla, L.B.; Pattanaik, A.; Lee, S.W. Evaluation of molybdenum recovery from sulfur removed spent catalyst using leaching and solvent extraction. Sci. Rep. 2020, 10, https://doi.org/10.1038/s41598-020-58972-x.

45. Jensen, A.B.; Webb, C. Ferrous sulphate oxidation using Thiobacillus ferrooxidans: a review. Proc. Biochem. 1995, 30, 225-236, https://doi.org/10.1016/0032-9592(95)85003-1.

46. Kim, D.J.; Pradhan, D.; RoyChaudhury, G.; Ahn, J.G.; Lee, S.W. Bioleaching of complex sulfides concentrate and correlation of leaching parameters using multivariate data analysis technique. Mater. Trans. 2009, 50, 2318-2322, https://doi.org/10.2320/matertrans.M2009125. 